\title{
Fatigue Properties of AA6060-T6 Butt Welds Made by Hybrid Metal Extrusion \& Bonding (HYB)
}

\author{
Lise Sandnes $^{1}, \varnothing_{\text {ystein Grong }}{ }^{1}$, Torgeir Welo ${ }^{1}$, and Filippo Berto ${ }^{1}$ \\ ${ }^{1}$ Norwegian University of Science and Technology
}

May 14, 2020

\begin{abstract}
The present investigation is concerned with high-cycle axial fatigue testing of a $2 \mathrm{~mm}$ AA6060-T6 HYB butt weld produced in the solid state using AA6082 filler metal addition. The results complement the three-point bend testing and the tensile testing done in two previous studies. In this study, optical microscope and scanning electron microscope examinations have been carried out to reveal the joint macro/microstructure and document possible surface and root defects deemed to affect fatigue life. In the as-welded condition, the HYB weld suffers from surface irregularities at the weld face and "kissing" bond formation in the root region. Despite of this, the subsequent testing shows that the fatigue properties exceed those reported for comparable AA6082-T6 gas metal arc butt welds and matching those reported for corresponding high-strength laser beam and friction stir weldments.
\end{abstract}

\section{Hosted file}

Fatigue testing of $2 \mathrm{~mm}$ HYB AA6060-T6 butt weld_v5.docx available at https://authorea.com/ users/314396/articles/451227-fatigue-properties-of-aa6060-t6-butt-welds-made-by-hybridmetal-extrusion-bonding-hyb 